\title{
The effect of transformational leadership, organizational communication and job involvement toward withdrawal behavior
}

\author{
Laode Muh. Al Basyir ${ }^{a^{*}}$, R. Madhakomala ${ }^{b}$ and Agung Wahyu Handaru ${ }^{b}$
}

${ }^{a}$ Post Graduate Study, State University of Jakarta, Jakarta, Indonesia

${ }^{b}$ State University of Jakarta, Jakarta, Indonesia

CHRONICLE ABSTRACT

Article history:

Received: November 3, 2019

Received in revised format: November 282019

Accepted: December 3, 2019

Available online:

December 3, 2019

Keywords:

Job involvement

Organizational communication

Transformational leadership

Withdrawal behavior

\begin{abstract}
The objective of this causal research was to obtain information concerning: 1 . the negative effect of leadership transformational toward withdrawal behavior, 2. the negative effect of organizational communication toward withdrawal behavior, 3 the negative effect of job involvement toward withdrawal behavior, 4 . the positive effect of transformational leadership toward job involvement, and 5. the positive effect of organizational communication toward job involvement. The research was conducted by SEM method for testing the hypotheses. In this research, state civil apparatus at the Regional Secretariat of the Southeast Sulawesi has been chosen as a unit analysis and 215 samples of employees were selected randomly. The results of the research are as follows: (1) there is a negative effect of leadership transformational toward withdrawal behavior; (2) there is a negative effect of organizational communication toward withdrawal behavior; (3) there is a negative effect of job involvement toward withdrawal behavior; (4) there is a positive effect of transformational leadership toward job involvement; (5) there is a positive effect of organizational communication toward job involvement.
\end{abstract}

\section{Introduction}

In the current era of globalization, State Civil Apparatur (ASN) is the most desirable profession for the younger generation, reflected by the great number of applicants. The enthusiasm of the applicants encourages the government to compile and establish the professional standards of ASN to address the extent and complexity of demands from the community to obtain and experience good and quality service from ASN as a form of their dedication to the nation and state. Since the reform era, ASN is an element that has always been the main focus of the community in the administration of government. In line with that, there are various complaints and protests from the community regarding the services provided by ASN in various agencies that are deemed to be inadequate, such as long and unclear service time, low quality of services, low level of attendance (frequent lateness), low motivation to work, and lack of initiative and creativity at work. The lack of professionalism of ASN is regrettably a common sight in various agencies, particularly in regions. Local governments are an extension of the central government to carry out the objectives and programs of national development in regions. One of the local governments are the Provincial Government of Southeast Sulawesi, whose vision is the development of Southeast Sulawesi through the accomplishment of safe, advanced, prosperous and dignified Southeast Sulawesi and mission is to improve the quality of life of the community, promote regional competitiveness by strengthening local economy and investment, realizing good government and good governance, and increasing connectivity and partnerships between government, private sectors and community. The implementation of the vision and mission of the Provincial Government of Southeast Sulawesi in this past 5 (five) years, particularly quality services to the community, has been not optimal, marked by employee withdrawal

* Corresponding author.

E-mail address: laodemuh_im16s3@mahasiswa.unj.ac.id (L. M. Al Basyir)

C 2020 by the authors; licensee Growing Science, Canada doi: $10.5267 /$ j.msl.2019.12.004 
behaviors. It encourages the government to impose disciplinary sanctions to 82 (eighty two) ASN as a result of a number of both minor and major violations. Based on the data obtained through field observations from August to December 2018, a number of ASN of the Provincial Government of Southeast Sulawesi, particularly within the scope of the Regional Secretariat of Southeast Sulawesi, violate applicable laws and regulations, specifically regarding discipline and obedience to applicable norms or regulations, evidenced by the high level of absenteeism. It is presented in Table 1 as follows,

\section{Table 1}

The Data of Morning and Afternoon Attendance of ASN in the Regional Secretariat of Southeast Sulawesi from January to December 2018

\begin{tabular}{lccccc}
\hline Month & ASN with low attendance & Percentage (\%) & Month & ASN with low attendance & Percentage (\%) \\
\hline January & 199 & 31.44 & July & 31.28 & 198 \\
February & 249 & 39.34 & August & 273 \\
March & 250 & 39.49 & September & 196 \\
April & 301 & 47.55 & October & 199 \\
May & 277 & 43.76 & November & 207 \\
June & 204 & 32.23 & December & 31.44 & 243 \\
\hline Source: The Bureau of Organization and Management, 2019 & & & 32.7 \\
\end{tabular}

Table 1 illustrates the high level of absenteeism of ASN in the Regional Secretariat of the Southeast Sulawesi from January to December 2018, indicating withdrawal behavior of ASN from their organization. As stated by Robbins and Judge (2013), "withdrawal behavior is the set of actions that employees take to separate themselves from the organization. There are many forms of withdrawal, ranging from showing up late or failing to attend meetings to absenteeism and turnover." A study by Simanjuntak and Rahardja (2013) discovers the high absenteeism and lack of employee performance to carry out their work with extra time. Meanwhile, working with extra time reduces the rate of lateness and minimizes the number of employees wishing to move or withdraw. According to Muliana and Makmur (2016), employee withdrawal is caused by low work involvement and lack of job satisfaction, resulting in lateness and absenteeism. According to Stephen and Robins (2012) "The voluntary and involuntary permanent withdrawal from an organization can be a problem because of increased recruiting, selection, and training costs and work disruptions. Just like absenteeism, managers can never eliminate withdrawal behavior, but it is something they want to minimize, especially among high-performing employees.". Low timely attendance of ASN at the Regional Secretariat of the Southeast Sulawesi reflects low work involvement. In fact, there are employees remain distrustful of their management and leaderships. They perceive that the organization does not treat the employees fairly in relation to providing rewards and imposing sanctions. Observed from the attitude of employees, it is highly possible that they go to work merely to fulfil their obligation to be present in the office. They extend their lunch break to reduce their working time. They are not proud of their division and not creative and innovative for the progress of the organization. Referring to previous studies by Malinen et al. (2013) and Mannarini and Fedi (2012), creating a good working atmosphere in the organization, particularly in terms of employee involvement, shall affect employee withdrawal behavior. Responding to the conditions at the Regional Secretariat of the Southeast Sulawesi, it is necessary for the local government to establish programs or activities in order to increase the motivation of ASN, both the superiors and the subordinates, to achieve the vision and mission of the organization effectively through human capital investment in recruiting employees as well as selecting and maintaining the potential employees to avoid employee withdrawal behavior. In addition to lateness and absenteeism, the main causes of withdrawal include heavy risks, fairness, communication and security from conflicts within the organization. Declining productivity is also a sign of employee withdrawal behavior. The Chairman of National Institute of Public Administration Indonesia (LAN), Suryanto (2017) delivers material regarding: "The Direction of HR Development Policy in Realizing Human Capital of ASN". It states that the development of ASN competencies must be carried out by prioritizing awareness, commitment, communication and coordination among stakeholders, particularly in planning competency development programs for ASN as mandated in the ASN Law and the Government Regulation on ASN Management (LAN RI, 2017). The awareness of the stakeholders is increased through coordination/communication between superiors and subordinates. The programs in the annual work meeting can incorporate various intensive training programs to discipline employees in order to accomplish effective ASN human capital. The level of withdrawal of ASN in the Provincial Government of Southeast Sulawesi, particularly the work unit of the Regional Secretariat, is assumed to be influenced by several factors, including:

First, Leadership: The administration of local government through regional autonomy mandates a change of leadership through direct election of Regional Heads every 5 (five) years, hence the changes in the structure of local government. Therefore, employee withdrawal is greatly affected by leadership. In this case, transformational leadership is considered to be the most effective leadership style due to its ability to influence, direct, guide, facilitate and motivate subordinates to work well to achieve organizational objectives.

Second, Organizational Communication: In carrying out their main duties and functions, ASN is required to continue to collaborate and cooperate with all elements to be able to carry out their work properly, effectively and efficiently. It can only be realized by a good communication between superiors and subordinates in the organization.

Third, Job Involvement: Involving staff in the implementation of work is a necessary action to motivate and encourage the confidence of the employees to work well. Thus, this study aims to discover: 
1) The direct effect of transformational leadership on withdrawal behavior;

2) The direct effect of organizational communication on withdrawal behavior;

3) The direct effect of job involvement on withdrawal behavior;

4) The direct effect of transformational leadership on job involvement;

5) The direct effect of organizational communication on job involvement.

This study is expected to be one of the theoretical references of scientific studies, particularly related to the concept of employee withdrawal currently discussed in several recent studies. The findings of this study are expected to be a reference for further studies. In practice, the findings of this study shall be used as input and consideration for local governments in determining strategic policies to reduce employee withdrawal in order to create good government and good governance.

\section{Theoretical study}

\subsection{Theoretical framework}

\subsubsection{Transformational Leadership and Withdrawal}

Transformational leadership is based on the correlation between the guidance and direction provided by the leaderships as well as the correlation between socio-emotional support provided by the leaderships and the readiness or maturity of the subordinates in carrying out specific tasks, functions or objectives. Considered the most effective style, transformational leadership is able to direct and develop subordinates, resulting in their reluctance to leave the organization or show withdrawal behavior. According to a study by Tangkudung et al. (2015), effective leadership style, in this regard transformational leadership, has a negative effect on withdrawal behavior. Similar findings are obtained by Rurkkhum and Bartlett (2018); Pravichai and Ariyabuddhiphongs (2018) and Hoel (2012). Meanwhile, a study by Long et al. (2012) discovers that leadership has no effect on employee withdrawal, indicating the need to be studied further in different types of organizations. Thus, it is assumed that transformational leadership has a negative effect on employee withdrawal behavior.

\subsubsection{Organizational Communication and Withdrawal}

Locke (2009) states that communication is a balance between the sender and receiver; between talking and listening; between what is said, how to say, and when it is expressed; between related tasks and activities; between conveying the types of trust; between using formal and informal connections; and between communicating with someone of the same age (if the said someone is a newcomer) and with someone with experience. This balance applies to individuals, teams, departments, or organizations (Locke, 2009). Studies by Holley et al. (2013) reveals that communication has an effect on withdrawal. Furthermore, Nwagbara et al. (2013) conclude that effective communication needs to be improved to reduce employee withdrawals. Thus, it is assumed that organizational communication has a negative effect on withdrawal.

\subsubsection{Job Involvement and Withdrawal}

Lachman and Diamant (1987) state that various models of psychological process lead to withdrawal behavior, implying that work environment as well as reaction to the job environment may cause either withdrawal behavior or greater focus in carrying out tasks in the organization. The job environment includes the indications of conflict, variety of tasks, financial rewards, relationships with colleagues and participation. In this regard, work participation is an indicator of job involvement. Mannarini and Fedi (2012) as well as Tangkudung (2015) discover that job involvement has an effect on employee withdrawal behavior. This finding is strengthened by Erdil and Muceldili (2014) that employees avoiding job involvement eventually show withdrawal behavior and apathy towards the organization. Meanwhile, Berry and Morris (2008) reveal that high productivity is an important key for employees in the workplace. By understanding the employees better, HR development division is able to notice employee withdrawal behavior and the effect of job involvement on the apathy of employees more easily in order to involve the employees in carrying out tasks (Berry \& Morris, 2008). Job involvement is described by Razzaq (2014) as psychological identification connected to the work and its related image. It indicates a correlation between job involvement and work performance. Employees with high motivation, commitment and job involvement show a lack of desire to withdraw from the organization (Razzaq, 2014). Zopiatis et al. (2014) and a similar finding is concluded by Gupta and Shaheen (2017) that the organization may contribute to the boredom and loss of enthusiasm of the employees. Thus, it is assumed that job involvement has a negative effect on employee withdrawal behavior.

\subsubsection{Transformational Leadership and Job Involvement}

Bass et al. (2003) in Hayati et al. (2014) state that transformational leadership comprises four areas, including idealistic influence, inspirational motivation, intellectual stimulation, and individual consideration. Individual consideration represents the attention and treatment provided by the superiors to the subordinates. Mubarak and Noor (2018) reveal that transformational leadership has a positive effect on job involvement. Similar finding is discovered in the studies by Evelyn and Hazel (2015); Engelbrecht et al. (2014); Othman et al. (2017); Ariyani \& Hidayat (2018), Akanji et al. (2018); as well as Ansari (2014). Thus, it is assumed that transformational leadership has a positive effect of on job involvement. 


\subsubsection{Organizational Communication and Job Involvement}

Locke (2009) states that communication is found in various forms, such as information, reference books, articles, newspapers, announcements, reports and emails. It indicates participatory involvement, achieving organizational goals through meetings, formal and informal discussions, negotiations, and sessions able to generate bright ideas or even encourage employees to achieve organizational objectives and develop relationships in the workplace (Locke, 2009). Business and Wesley (2017) discover that communication has an effect on job involvement. A study by Balakrishnan (2013) verifies a correlation between communication and job involvement utilizing five factors, namely: communication between superiors and subordinates, quality information, the openness of the superiors, the opportunities of upward communication, and the availability of communication. Thus, it is assumed that organizational communication has a positive effect on job involvement. Based on the theoretical study and framework of thinking, the hypotheses in this study are formulated as follows:

1. Transformational leadership has a negative effect on employee withdrawal behavior;

2. Organizational communication has a negative effect on employee withdrawal behavior;

3. Job involvement has a negative effect on employee withdrawal behavior;

4. Transformational leadership has a positive effect on job involvement.

5. Organizational communication has a positive effect on job involvement.

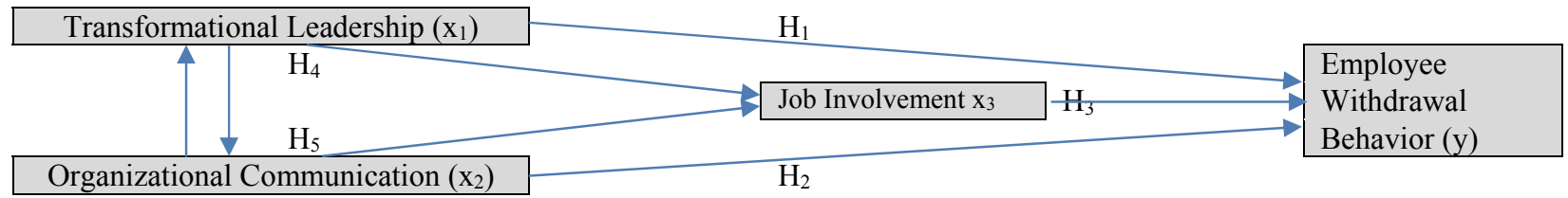

\section{Findings and discussion}

Fig. 1. Constellation Model

\subsection{Findings}

Inferential analysis with structural equation modeling is conducted in Two Step Approach. The first step is to measure the construct variables to form a latent variable with confirmatory factor analysis to obtain combined exogenous and exogenous construct model with a good fit. The CFA model is acceptable should it has a good data validity and reliability. The second step is testing the overall structural equation modeling by combining the measurement model and the structural model into an acceptable full model to be analyzed and estimated. The model is considered fit should it meets the overall criteria of goodness of fit and the criteria of the evaluation of structural model.

\subsubsection{Measurement Model Test Results}

\section{Confirmatory Factor Analysis (CFA) of Transformational Leadership (X1)}

Based on the output of Goodness of Fit Test for Exogenous Construct Model, most criteria are in the category of good fit. According to Ghozali (2012, p. 49), 4 - 5 criteria of goodness of fit are considered sufficient to assess the feasibility of a model, provided that criteria of goodness of fit, namely absolute fit indices, incremental fit indices, and parsimony indices, are utilized. Thus, it is concluded that Goodness of Fit of Confirmatory Factor Analysis (CFA) Model of Transformational Leadership (X1) is acceptable or the results are in accordance with the model.

\section{Table 2}

Goodness of Fit of Confirmatory Factor Analysis (CFA) Model of Transformational Leadership (X1)

\begin{tabular}{|c|c|c|c|c|}
\hline \multicolumn{5}{|l|}{ Absolut Fit Measure } \\
\hline Goodness-of-Fit & & Cut-off Value & Result & Fit \\
\hline p-value (Sig.) & $>0.05$ & & 0.493 & Good Fit \\
\hline Chi-Square/df & $\leq 3$ & & 0.905 & Good fit \\
\hline GFI & $\geq 0.90$ & & 0.983 & Good Fit \\
\hline RMSEA & & & $\cap \cap \cap \cap$ & Fond Fit \\
\hline RMR & $\leq 0.05$ & & 0.021 & Good Fit \\
\hline \multicolumn{5}{|c|}{ Incremental Fit Measure } \\
\hline Goodness-of-Fit & & Cut-off Value & Result & Fit \\
\hline AGFI & $\geq 0.90$ & & 0.961 & Good Fit \\
\hline CFI & $\geq 0.90$ & & 1.000 & Good Fit \\
\hline IFI & $\geq 0.90$ & & 1.001 & Good Fit \\
\hline RFI & $\geq 0.95$ & & 0.966 & Good Fit \\
\hline \multicolumn{5}{|c|}{ Parsimonious Fit Measure } \\
\hline PNFI & Small & & 0.560 & Good Fit \\
\hline PGFI & Approaching 1 & & 0.437 & Good fit \\
\hline $\mathrm{AIC}$ & $<72.000$ & & 55.439 & Good Fit \\
\hline CAIC & $<229.343$ & & 142.852 & Good Fit \\
\hline
\end{tabular}


2. Confirmatory Factor Analysis (CFA) of Organizational Communication (X2)

Table 3

Goodness of Fit of Confirmatory Factor Analysis (CFA) Model of Organizational Communication (X2) Absolut Fit Measure

\begin{tabular}{|c|c|c|c|c|}
\hline Goodness-of-Fit & & Cut-off Value & Result & Fit \\
\hline p-value (Sig.) & $>0.05$ & & 0.986 & Good Fit \\
\hline Chi-Square/df & $\leq 3$ & & 0.520 & Good Fit \\
\hline GFI & $\geq 0.90$ & & 0.986 & Good Fit \\
\hline RMSEA & $\leq 0.08$ & & 0.000 & Good Fit \\
\hline RMR & $\leq 0.05$ & & 0.014 & Good Fit \\
\hline \multicolumn{5}{|l|}{ Incremental Fit Measure } \\
\hline Goodness-of-Fit & & Cut-off Value & Result & Fit \\
\hline AGFI & $\geq 0.90$ & & 0.974 & Good Fit \\
\hline CFI & $\geq 0.90$ & & 1.000 & Good Fit \\
\hline IFI & $\geq 0.90$ & & 1.029 & Good Fit \\
\hline RFI & $\geq 0.95$ & & 0.955 & Good Fit \\
\hline \multicolumn{5}{|l|}{ Parsimonious Fit Measure } \\
\hline Goodness-of-Fit & & Cut-off Value & Result & Fit \\
\hline PNFI & Small & & 0.647 & Good Fit \\
\hline PGFI & Approaching 1 & & 0.538 & Marginal Fit \\
\hline $\mathrm{AIC}$ & $<110.000$ & & 65.601 & Good Fit \\
\hline CAIC & $<\underline{350.385}$ & & 174.867 & Good Fit \\
\hline
\end{tabular}

Based on the output of Goodness of Fit Test for Exogenous Construct Model, most criteria are in the category of good fit. According to Ghozali (2012, p. 49), 4 - 5 criteria of goodness of fit are considered sufficient to assess the feasibility of a model, provided that each criteria of goodness of fit, namely absolute fit indices, incremental fit indices, and parsimony indices, is utilized. Thus, it is concluded that Goodness of Fit of Confirmatory Factor Analysis (CFA) Model of Organizational Communication (X2) is acceptable or the results are in accordance with the model.

\section{Confirmatory Factor Analysis (CFA) of Job Involvement (X3)}

Based on the output of Goodness of Fit Test for Exogenous Construct Model, most criteria are in the category of good fit. According to Ghozali (2012, p. 49), 4 - 5 criteria of goodness of fit are considered sufficient to assess the feasibility of a model, provided that each criteria of goodness of fit, namely absolute fit indices, incremental fit indices, and parsimony indices, is utilized. Thus, it is concluded that Goodness of Fit of Confirmatory Factor Analysis (CFA) Model of Job Involvement (X3) is acceptable or the results are in accordance with the model.

Table 4

Goodness of Fit of Confirmatory Factor Analysis (CFA) Model of Job Involvement (X3)

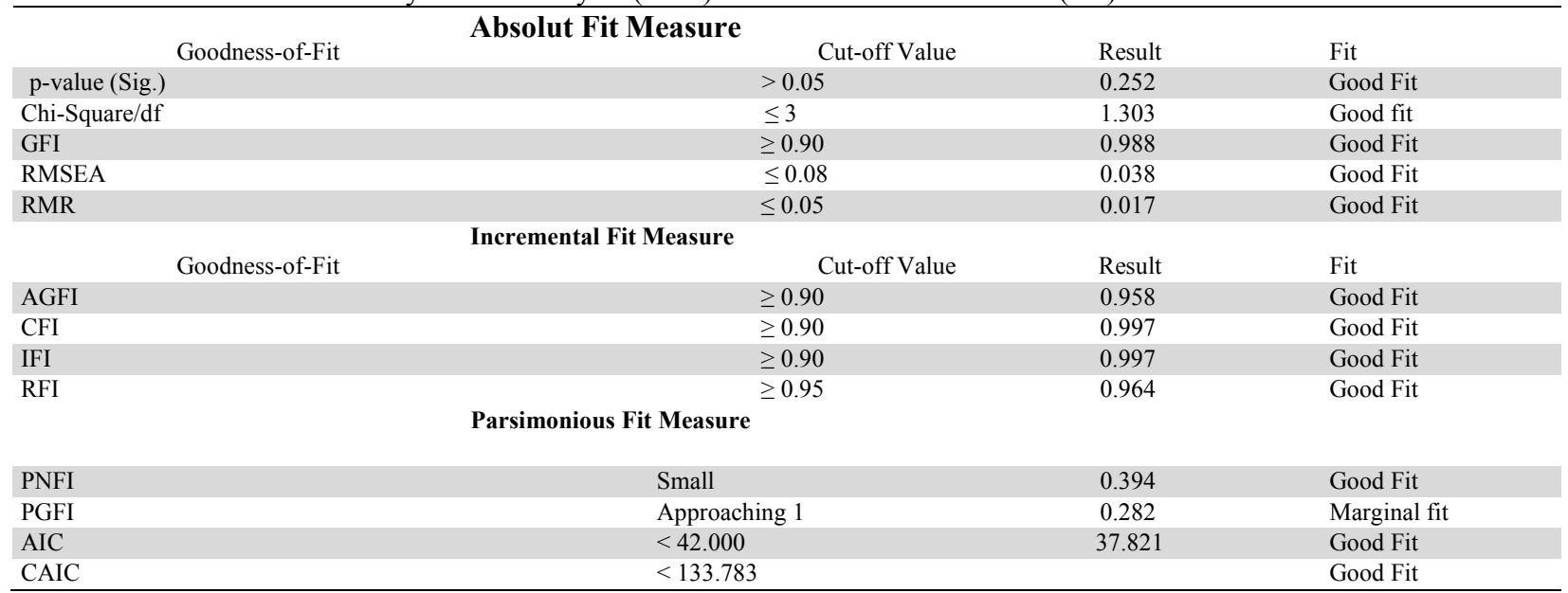

\section{Confirmatory Factor Analysis (CFA) of Withdrawal Behavior (Y)}

Based on the output of Goodness of Fit Test for Exogenous Construct Model, most criteria are in the category of good fit. According to Ghozali (2012, p. 49), 4 - 5 criteria of goodness of fit are considered sufficient to assess the feasibility of a model, provided that each criteria of goodness of fit, namely absolute fit indices, incremental fit indices, and parsimony indices, is utilized. Thus, it is concluded that Goodness of Fit of Confirmatory Factor Analysis (CFA) Model of Withdrawal Behavior (Y) is acceptable or the results are in accordance with the model. 
Table 5

Goodness of Fit of Confirmatory Factor Analysis (CFA) Model of Withdrawal Behavior (Y)

\begin{tabular}{|c|c|c|c|}
\hline \multicolumn{4}{|c|}{ Absolut Fit Measure } \\
\hline Goodness-of-Fit & Cut-off Value & Result & Fit \\
\hline p-value (Sig.) & $>0.05$ & 0.251 & Good fit \\
\hline Chi-Square/df & $\leq 3$ & 1.159 & Good Fit \\
\hline GFI & $\geq 0.90$ & 0.968 & Good Fit \\
\hline RMSEA & $\leq 0.08$ & 0.027 & Good Fit \\
\hline RMR & $\leq 0.05$ & 0.027 & Good Fit \\
\hline \multicolumn{4}{|c|}{ Incremental Fit Measure } \\
\hline Goodness-of-Fit & Cut-off Value & Result & Fit \\
\hline AGFI & $\geq 0.90$ & 0.941 & Good Fit \\
\hline CFI & $\geq 0.90$ & 0.995 & Good Fit \\
\hline IFI & $\geq 0.90$ & 0.995 & Good Fit \\
\hline RFI & $\geq 0.95$ & 0.949 & Good Fit \\
\hline \multicolumn{4}{|c|}{ Parsimonious Fit Measure } \\
\hline PNFI & Small & 0.644 & Good Fit \\
\hline PGFI & Approaching 1 & 0.528 & Marginal fit \\
\hline $\mathrm{AIC}$ & $<110.000$ & 84.783 & Good Fit \\
\hline CAIC & $<350.385$ & 194.049 & Good Fit \\
\hline
\end{tabular}

\subsubsection{Full Structural Model Test Results (SEM)}

To test the significance of the path coefficient the direct effect can be seen in the Path Coefficient table and C.R. ( $t$-value). Based on the results of Table 6, the estimated value of each parameter and the accuracy value of the model and the CR value produce the following analysis: (1) Transformational leadership has a direct negative effect on employee withdrawal behavior with the results of the analysis showing a significant estimated value $(b=-0.444 ; p>0.05 ; C R=-5.097)$ where the direct effect is measured by $\mathrm{CR}$ values $<-1.96$ and $\mathrm{CR}>1.96$. (2) Organizational communication has a direct negative effect on employee withdrawal behavior with the results of the analysis showing a significant estimated value $(b=-0.264 ; p>0.05$; $\mathrm{CR}=-3.167$ ) where the direct effect is measured by $\mathrm{CR}$ values $<-1.96$ and $\mathrm{CR}>1.96$. (3) Job involvement has a direct negative effect on employee withdrawal behavior with the results of the analysis showing a significant estimated value $(b=-$ $0.298 ; \mathrm{p}>0.05 ; \mathrm{CR}=-3.542$ ) where the direct effect is measured by $\mathrm{CR}$ values $<-1.96$ and $\mathrm{CR}>1.96$. (4) Transformational leadership has a direct positive effect on job involvement with the results of the analysis showing a significant estimation value $(b=-0.296 ; p>0.05 ; C R=3.455)$ where the direct effect is measured by $C R$ values $<-1.96$ and $C R>1,96$. (5) Organizational communication has a positive direct effect on job involvement with the results of the analysis showing a significant estimation value $(b=-0.266 ; p>0.05 ; C R=2.9)$ where the direct effect is measured by the $C R$ value $<-1.96$ and $C R>1.96$.

Table 6

Path Coefficient table and C.R. (t-value)

\begin{tabular}{|c|c|c|c|c|c|c|c|}
\hline & & & $\begin{array}{c}\text { Standardized } \\
\text { Estimate }\end{array}$ & $\begin{array}{c}\text { Unstandardized } \\
\text { Estimate }\end{array}$ & S.E. & C.R. & $\mathrm{P}$ \\
\hline $\begin{array}{l}\text { Withdrawal } \\
\text { Behavior_Y }\end{array}$ & $\leftarrow$ & $\begin{array}{c}\text { Transformational_ } \\
\text { Leadership_X1 }\end{array}$ &,- 444 &,- 505 & ,099 & $-5,097$ & $* * *$ \\
\hline $\begin{array}{l}\text { Withdrawal_ } \\
\text { Behavior_Y }\end{array}$ & $\leftarrow$ & $\begin{array}{l}\text { Organizational_- } \\
\text { Communication_X2 }\end{array}$ &,- 264 &,- 413 &, 131 & $-3,167$ &, 002 \\
\hline $\begin{array}{l}\text { Withdrawal_ } \\
\text { Behavior_Y }\end{array}$ & $\leftarrow$ & Job_Involvement_X3 &,- 298 &,- 308 & ,087 & $-3,542$ & $* * *$ \\
\hline $\begin{array}{c}\text { Job_- } \\
\text { Involvement X3 }\end{array}$ & $\leftarrow$ & $\begin{array}{c}\text { Transformational_ } \\
\text { Leadership_X1 }\end{array}$ & ,296 & ,326 & ,094 & 3,455 & $* * *$ \\
\hline $\begin{array}{c}\text { Job_- } \\
\text { Involvement_X3 }\end{array}$ & $\leftarrow$ & $\begin{array}{l}\text { Organizational_- } \\
\text { Communication_X2 }\end{array}$ & ,266 & ,403 & ,139 & 2,901 & ,004 \\
\hline
\end{tabular}

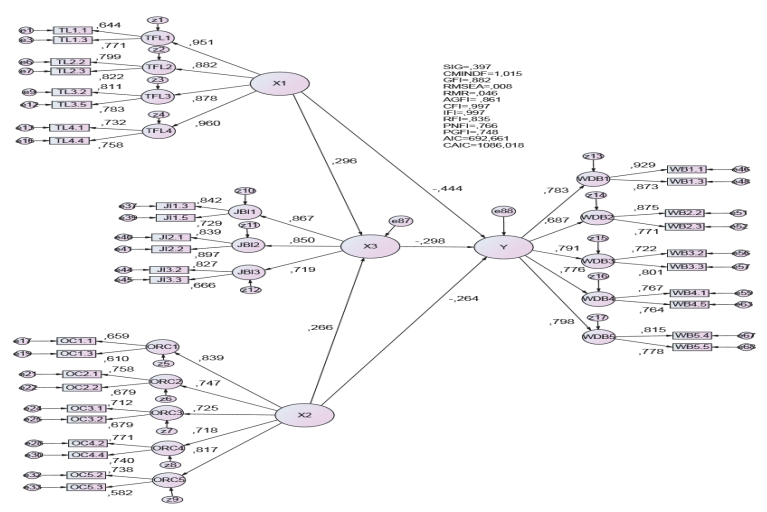

Fig. 2. Full Structural Model (SEM) 
The previous picture shows that all values of loading factor analysis obtain $\geq 0.05$. It indicates that all observed indicators can be used to measure each variable in this study. Table 7 presents the goodness of fit test of full model (SEM):

Table 7

Goodness of Fit Test of Full Model (SEM)

\begin{tabular}{lcll} 
& Goodness-of-Fit & Absolut Fit Measure & \\
Cut-off Value & Result & Fit \\
p-value (Sig.) & $>0.05$ & 0.397 & Good Fit \\
Chi-Square/df & $\leq 3$ & 1.015 & Good fit \\
GFI & $\geq 0.90$ & 0.882 & Marginal fit \\
RMSEA & $\leq 0.08$ & 0.008 & Good fit \\
RMR & $\leq 0.05$ & 0.046 & Good fit \\
& Incremental Fit Measure & & Fit \\
AGFI & Cut-off Value & Result & Marginal fit \\
CFI & $\geq 0.90$ & 0.861 & Good fit \\
IFI & $\geq 0.90$ & 0.997 & Good fit \\
RFI & $\geq 0.90$ & 0.997 & Marginal fit \\
& $\geq 0.95$ & 0.835 & Marginal fit \\
PNFI & Parsimonious Fit Measure & & Good fit \\
PGFI & Small & 0.766 & Good fit \\
AIC & Approaching 1 & 0.748 & Good fit \\
CAIC & $<1190.000$ & 692.661 & 1086.018 \\
\hline
\end{tabular}

Based on the output of Goodness of Fit Test for Full Model (SEM), most criteria are in the category of good fit. According to Ghozali (2012, p. 49), 4 - 5 criteria of goodness of fit are considered sufficient to assess the feasibility of a model, provided that all criteria of goodness of fit, namely absolute fit indices, incremental fit indices, and parsimony indices are utilized. Thus, it is concluded that Goodness of Fit of Full Model (SEM) is acceptable or there is no significant difference between the covariance matrix of the observed variable (construct) and the covariance matrix of the specified model. It shows that the structural equation generated by the model can be used to explain the influence between exogenous variables and their endogenous variables.

\section{Discussion}

\section{Transformational Leadership Has a Negative Effect on Employee Withdrawal Behavior}

It signifies that the effective leadership carried out by the leaderships or superiors of the Regional Secretariat of Southeast Sulawesi shall lead to a decrease in the employee withdrawal at the Regional Secretariat of Southeast Sulawesi. It is understandable considering that effective leadership is essential to support the success of the organization, particularly in reducing employee withdrawal. It is evident from the statement by Greenberg (2010) that withdrawal behavior is the lack of employee commitment to the organization, reflected in the increasing desire of the employees to resign or absent. The employees with a great commitment to the organization shall maintain their job and show positive behaviors regarding their duties (Greenberg, 2010). Based on the study by Tangkudung et al. (2015), leadership shows a coefficient value of 0.115 , indicating that each scale of 1 means an increase of leadership style by 0.115 to withdrawal behavior. It is also strengthened by the studies by Rurkkhum and Bartlett (2018); Pravichai and Ariyabuddhiphongs (2018) and Hoel (2012) that transformational leadership has a negative effect on withdrawal. The results of statistical tests further strengthen the theories explaining a negative effect of transformational leadership on employee withdrawal.

\section{Organizational Communication Has a Negative Effect on Employee Withdrawal Behavior}

It means that communication carried out by the leaderships or superiors as well as fellow employees of the Regional Secretariat of Southeast Sulawesi shall lead to a decrease in the employee withdrawal at the Regional Secretariat of Southeast Sulawesi. It is understandable considering that communication is essential to support the success of the organization, particularly in reducing employee withdrawal. It is evident from the statement by Locke (2009) that communication is a balance between the sender and receiver; between talking and listening; between what is said, how to say, and when it is expressed; between related tasks and activities; between conveying the types of trust; between using formal and informal connections; and between communicating with someone of the same age (if the said someone is a newcomer) and with someone with experience. This balance applies to individuals, teams, departments, or organizations (Locke, 2009). Studies by Holley et al. (2013) reveal that communication has an effect on withdrawal. Furthermore, Nwagbara et al. (2013) conclude that effective communication needs to be improved to reduce employee withdrawals. The results of statistical tests further strengthen the theories explaining a negative effect of organizational communication on employee withdrawal.

\section{Job Involvement Has a Negative Effect on Employee Withdrawal}

It signifies that job involvement carried out by employees of the Regional Secretariat of Southeast Sulawesi shall lead to the decrease in employee withdrawal at the Regional Secretariat of Southeast Sulawesi. It is understandable considering that job involvement is essential to support the success of the organization, particularly in reducing employee withdrawal. It refers to the statement by Lachman and Diamant (2007) that various models of psychological process lead to withdrawal behavior, 
implying that job environment as well as reaction to the job environment may cause either withdrawal behavior or greater focus in carrying out tasks in the organization (Lachman \& Diamant, 2007). The job environment includes the indications of conflict, variety of tasks, financial rewards, relationships with colleagues and participation. In this regard, work participation is an indicator of job involvement. A previous study by Tangkudung et al. (2015) prove that job involvement has an effect on employee withdrawal behavior. This finding is strengthened by Erdil and Muceldili (2014) that employees avoiding job involvement eventually show withdrawal behavior and apathy towards the organization. Meanwhile, Berry and Morris (2008) reveal that high productivity is an important key for employees in the workplace. By understanding the employees better, HR development division is able to notice employee withdrawal behavior and the effect of job involvement on the apathy of employees more easily in order to involve the employees in carrying out tasks (Berry \& Morris, 2008). Job involvement is described by Razzaq (2014) as psychological identification connected to the work and its related image. It indicates a correlation between job involvement and work performance. Employees with high motivation, commitment and job involvement show a lack of desire to withdraw from the organization (Razzaq, 2014). Zopiatis et al. (2014) discover an indirect effect of job involvement on withdrawal through job satisfaction. A similar finding is concluded by Gupta and Shaheen (2017) that the organization may contribute to the boredom and loss of enthusiasm of the employees. The results of statistical tests further strengthen the theories explaining a negative effect of job involvement on employee withdrawal.

\section{Transformational Leadership Has a Positive Effect on Job Involvement}

It means that effective leadership carried out by superiors or leaderships of the Regional Secretariat of Southeast Sulawesi shall lead to the increase in job involvement of employees at the Regional Secretariat of Southeast Sulawesi. It is understandable considering that effective leadership is essential to support the success of the organization, particularly in increasing employee involvement. It is evident from the statement by Bass et al (2003) in Hayati, Charkhabi and Naami transformational leadership comprises four areas, including idealistic influence, inspirational motivation, intellectual stimulation, and individual consideration. Individual consideration represents the attention and treatment provided by the superiors to the subordinates (Hayati et al., 2014). Mubarak and Noor (2017) reveal that effective leadership has a role in increasing job involvement. Thus, leadership has a strong positive correlation with job involvement (Mubarak and Noor, 2018). A study by Evelyn (2015) reveals the effect of transformational leadership on job involvement. Similar findings are discovered in the studies by: Engelbrecht, Heine, Mahembe, and Africa (2014); Othman, Hamzah, and Abas (2017); Ariyani \& Hidayat (2018), Akanji, Ajonbadi, and Mojeed-sanni (2018); as well as Malik and Ansari (2014). The results of statistical tests further strengthen the theories explaining a positive effect of transformational leadership on job involvement.

\section{Organizational Communication Has a Positive Effect on Job Involvement}

It signifies that organizational communication carried out by the superiors or leaderships of the Regional Secretariat of Southeast Sulawesi shall lead to the increase in job involvement of employees at the Regional Secretariat of Southeast Sulawesi. It is understandable considering that effective communication is essential to support the success of the organization, particularly in increasing employee involvement. It is supported by Locke (2009) stating that communication is found in various forms, such as information, reference books, articles, newspapers, announcements, reports and emails. It indicates participatory involvement, achieving organizational goals through meetings, formal and informal discussions, negotiations, and sessions able to generate bright ideas or even encourage employees to achieve organizational objectives and develop relationships in the workplace (Locke, 2009). Business and Wesley (2017) discover that communication has an effect on job involvement. A study by Balakrishnan (2013) verifies a correlation between communication and job involvement utilizing five factors, namely: communication between superiors and subordinates, quality information, the openness of the superiors, the opportunities of upward communication, and the availability of communication. The results of statistical tests further strengthen the theories explaining a positive effect of communication on job involvement.

\section{Conclusion and suggestions}

\subsection{Conclusion}

The improvement of the characteristics of leaderships in carrying out their roles and functions as superiors shall decrease employee withdrawal behavior in the Regional Secretariat of the Southeast Sulawesi. Improvement of the character of transformational leadership characterized by positive attitude possessed by the leaders will cause a decrease in the level of withdrawal of employees. The improvement of organizational communication in the implementation of Main Duties and Functions by employees shall decrease employee withdrawal behavior in the Regional Secretariat of the Southeast Sulawesi. Improvement of organizational communication marked by the existence of good communication between leaders and subordinates at work will led to a decrease in the level of withdrawal of employees. The improvement of job involvement in the implementation of Main Duties and Functions by employees shall decrease employee withdrawal behavior in the Regional Secretariat of the Southeast Sulawesi. Improvement of job involvement which is marked by the positive attitudes possessed by every employee in the organization both of the leadership and subordinate elements will cause a decrease in the level of withdrawal of employees. The improvement of the characteristics of leaderships in carrying out their roles and functions as superiors shall increase employee involvement in the Regional Secretariat of the Southeast Sulawesi. Improvement of transformational leadership marked by positive attitudes applied by superiors or leaders such as superiors provide direction to subordinates in carrying out tasks, principal and its function will lead to an increase in employee job invovement. The improvement of organizational communication in the implementation of Main Duties and Functions by employees shall 
increase employee job involvement in the Regional Secretariat of the Southeast Sulawesi. Improvement of organizational communication marked by good communication between leaders and subordinates and good attitude to be a speaker and listener will cause increased job involvement in the employees.

\subsection{Suggestions}

The Provincial Government of Southeast Sulawesi is expected to consider the application of policies in an effort to reduce employee withdrawal in the Regional Secretariat of the Southeast Sulawesi, including: First, the need to improve guidance on the characteristics of leaderships for all Heads of Regional Apparatus Organizations through education and training, Technical Guidance, Forum Group Discussion, as well as Seminar related to Transformational Leadership to assist the leaderships in discovering the tips to provide a positive motivation and influence for employees at their respective work units. Second, the need to improve good communication between all elements through work meetings, coordination, discussion groups, monitoring and evaluation. Third, the need to increase the intensity of work involvement of all employees in an equitable manner in accordance with the standard operational procedures for the distribution of main duties and functions in order to increase self-confidence and motivation as well as decrease employee withdrawal in the Regional Secretariat of Southeast Sulawesi.

\section{References}

Akanji, B., Ajonbadi, H., \& Mojeed-sanni, B. (2018). Impact of leadership styles on employee engagement and conflict management practices in Nigerian universities Research question. Educational Research. 28(4), 830-848.

Ansari, A. H. (2014). The relationship between leadership styles and job involvement: An empirical study of Indian employees Shehla Malik*, (2000). Centre for Management Studies.

Ariyani, N., \& Hidayati, S. (2018). Influence of Transformational Leadership and Work Engagement On Innovative Behavior. Etikonomi, 17(2), 275-284.

Balakrishnan, C. (2013). Impact of internal communication on employee engagement - A study at Delhi International Airport. International Journal of Scientific and Research Publications, 3(8), 1-13.

Berry, M. L., \& Morris, M. L. (2018). The Impact of Employee Engagement Factors and Job Satisfaction On Withdrawal Intent. Erick Collection Thesaurus.

Business, G., \& Wesley, R. (2017). A study on impact of employee communication on employee. Global Business and Management Research. An International Journal, 6, 54-64.

Engelbrecht, A. S., Heine, G., \& Mahembe, B. (2014). The influence of ethical leadership on trust and work engagement: An exploratory study. SA Journal of Industrial Psychology, 40(1), 1-9.

Erdil, O., \& Müceldili, B. (2014). The effects of envy on job engagement and turnover intention. Procedia-Social and Behavioral Sciences, 150, 447-454.

Evelyn, D., \& Hazel, G. (2015). Effects of Transformational Leadership on Employee Engagement: The Mediating Role of Employee Engagement. International Journal of Management, 6(2), 01-08.

Ghozali, I. L. (2012). Aplikasi Analisis Multivariat dengan Program SPSS.

Greenberg, P. (2010). The impact of CRM 2.0 on customer insight. Journal of Business \& Industrial Marketing, 25(6), 410419.

Gupta, M., \& Shaheen, M. (2017). Impact of work engagement on turnover intention: moderation by psychological capital in India. Business: Theory and Practice, 18, 136-147.

Hayati, D., Charkhabi, M., \& Naami, A. Z. (2014). The relationship between transformational leadership and work engagement in governmental hospitals nurses: A survey study. SpringerPlus. https://doi.org/10.1186/2193-1801-3-25

Graen, G. B., Liden, R. C., \& Hoel, W. (1982). Role of leadership in the employee withdrawal process. Journal of Applied Psychology, 67(6), 868.

Karanges, E., Beatson, A., Johnston, K., \& Lings, I. (2014). Optimizing Employee Engagement with Internal Communication : A Social Exchange Perspective. International Journal of Business Marketing Management, 7, $329-353$.

Lachman, R., \& Diamant, E. (1987). Withdrawal and restraining factors in teachers' turnover intentions. Journal of Organizational Behavior, 8(3), 219-232.

Locke, E. A. (2009). Handbook of Principles of Organizational Behavior: Indispensable Knowledge for Evidence-Based Management. Handbook of principles of organizational behavior. https://doi.org/10.1002/9781119206422.ch16

Long, C. S., Thean, L. Y., Ismail, W. K. W., \& Jusoh, A. (2012). Leadership styles and employees' turnover intention: Exploratory study of academic staff in a Malaysian College. World Applied Sciences Journal, 19(4), 575-581.

Malinen, S., Wright, S., \& Cammock, P. (2013, April). What drives organisational engagement? A case study on trust, justice perceptions and withdrawal attitudes. In Evidence-based HRM: A Global Forum for Empirical Scholarship (Vol. 1, No. 1, pp. 96-108). Emerald Group Publishing Limited.

Mannarini, T., \& Fedi, A. (2012). Persisting or Withdrawing? An Insight into the Psychosocial Processes Underlying Sustained Engagement, 315(August 2011), 300-315. https://doi.org/10.1002/casp. John Wiley \& Sons, Ltd.

Mubarak, F., \& Noor, A. (2018). Effect of authentic leadership on employee creativity in project-based organizations with the mediating roles of work engagement and psychological empowerment. Cogent Business \& Management, 65(1), 1-14.

Muliana, Y., \& Makmur, W. A. (2016). Pengaruh Keterlibatan Kerja dan Kepuasan Kerja terhadap Turnover Intention Karyawan pada Pasar Modern Pasir Pengaraian Kabupaten Rokan Hulu. 
Holley, Sarah., Haase, Claudia., \& Levenson, Robert. (2013). Age-related changes in demand - withdraw communication behaviors, 75(August), 822-836.

Nwagbara, U., Oruh, E. S., Ugorji, C., \& Ennsra, M. (2013). The impact of effective communication on employee withdrawal at first bank of Nigeria, Royal Hill ,2(4), 13-21.

Othman, A. K., Hamzah, M. I., \& Abas, M. K. (2017). Othman, A. K., Hamzah, M. I., Abas, M. K., \& Zakuan, N. M. (2017). The influence of leadership styles on employee engagement: The moderating effect of communication styles. International Journal of Advanced and Applied Sciences, 4(3), 107-116.

Pravichai, S., \& Ariyabuddhiphongs, V. (2018). Transformational leadership and turnover intention: the mediating effects of right speech (Samma Vaca) and trust in the leader. Journal of Management, Spirituality \& Religion, 15(3), $253-272$.

Razzaq, M. A. (2014). Impact of job involvement, commitment, job satisfaction on Withdrawal: An Empirical Investigation on Banking Sector, IISTE,4(2), 35-43.

Robbins, S., \& Judge, T. A. (2013). Organizational Behavior 15th ed., McGraw-Hill.

Rurkkhum, S., \& Bartlett, K. R. (2018). Organizational citizenship behaviour for collectivist cultures: instrument development and human resource development implications. Human Resource Development International, 21(2), 107-124.

Simanjuntak, N., \& Rahardja, E. (2013). Kerja terhadap Withdrawal Karyawan ( Studi pada PT . Njonja Meneer Semarang ). Diponegoro Journal of management, 2, 1-10.

Stephen, P., \& Robins, M. C. (2012a). Management 11th Edition. Pearson Education.Inc. https://doi.org/10.1002/15213773(20010316)40:6<9823::AID-ANIE9823>3.3.CO;2-C

Stephen, P., \& Robins, M. C. (2012b). Management And Organization. Angewandte Chemie International Edition. https://doi.org/10.1002/1521-3773(20010316)40:6<9823::AID-ANIE9823>3.3.CO;2-C. Pearson Education., Inc.

Suryanto, T. (2017). Cultural Ethics and Consequences in Whistle-Blowing Among Professional Accountants: An Empirical Analysis. Journal of Applied Economic Sciences, 12(6).

Tangkudung, Saerang, Tielung. (2015). Analysis the effect of leadership style and job environment towards employee withdrawal behavioral. Jurnal Berkala Ilmiah Efisiensi. IBA Program.

Zopiatis, A., Constanti, P., \& Theocharous, A. L. (2014). Job involvement, commitment, satisfaction and turnover : Evidence from hotel employees in Cyprus . Central Lancashire online Knowledge. Tourism Management, 41, 129-140.

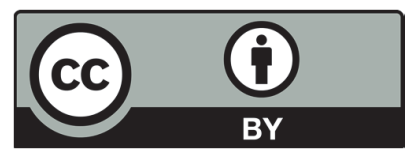

(C) 2020 by the authors; licensee Growing Science, Canada. This is an open access article distributed under the terms and conditions of the Creative Commons Attribution (CC-BY) license (http://creativecommons.org/licenses/by/4.0/). 